\title{
SOCIETY NEWS
}

The usual awards were presented at the annual meeting in Regina in October. The Conservation Award was received this year by Lorne Lepp to honour him for his efforts in environmental education and conservation. He worked to protect the sand dunes of Good Spirit Lake Provincial Park through the masterplan. He was a major force in the establishment of the Elizabeth Priestly Nature Trail at York Lake, for which he developed interpretive brochures. His active promotion of the trail for school use is followed by participating in the Project Wild program this year, bringing wildlife education indoors. The crowning achievement has been the establishment of the Yorkton Ecological Park, where a ravine and marsh have been preserved within the city limits of Yorkton. Here a nature trail has been established and a fine piece of habitat has been preserved.

From the participants who showed their slides at the annual meeting Carol Bjorklund of Bromhead, Saskatchewan was chosen to receive the Larry Morgotch Award. Her series of slides depicted the story of the rescue of an owl when the nest was blown down.

The Cliff Shaw Award this year goes to Jean and George Hilton for their report of a Rufous Humminbird, which appeared in the March 1985 Blue Jay [43(1):54-55]. Their account gave a description of the field marks used to identify the bird and included behavioral characteristics. The article is an example of accurate observation of nature.

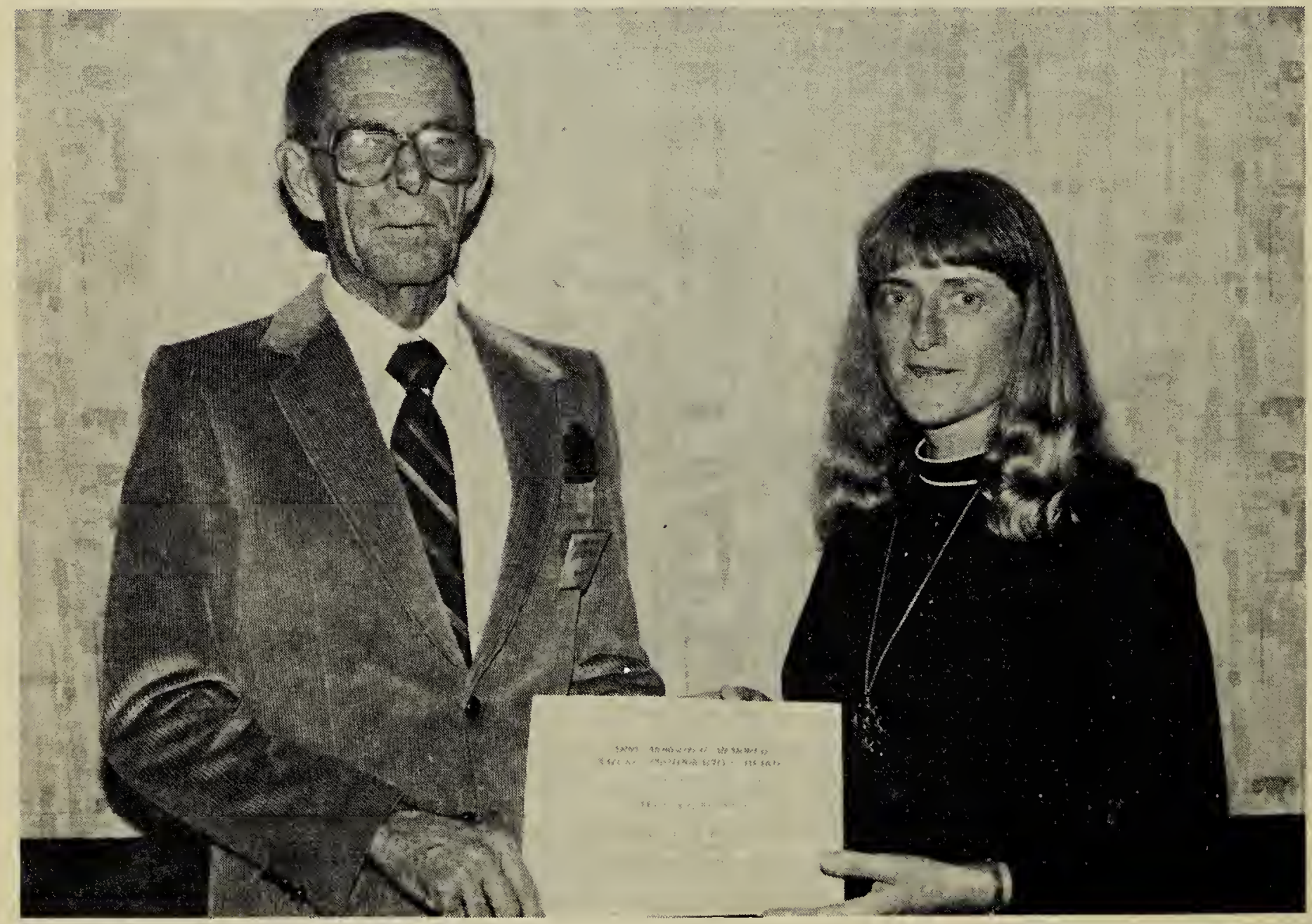




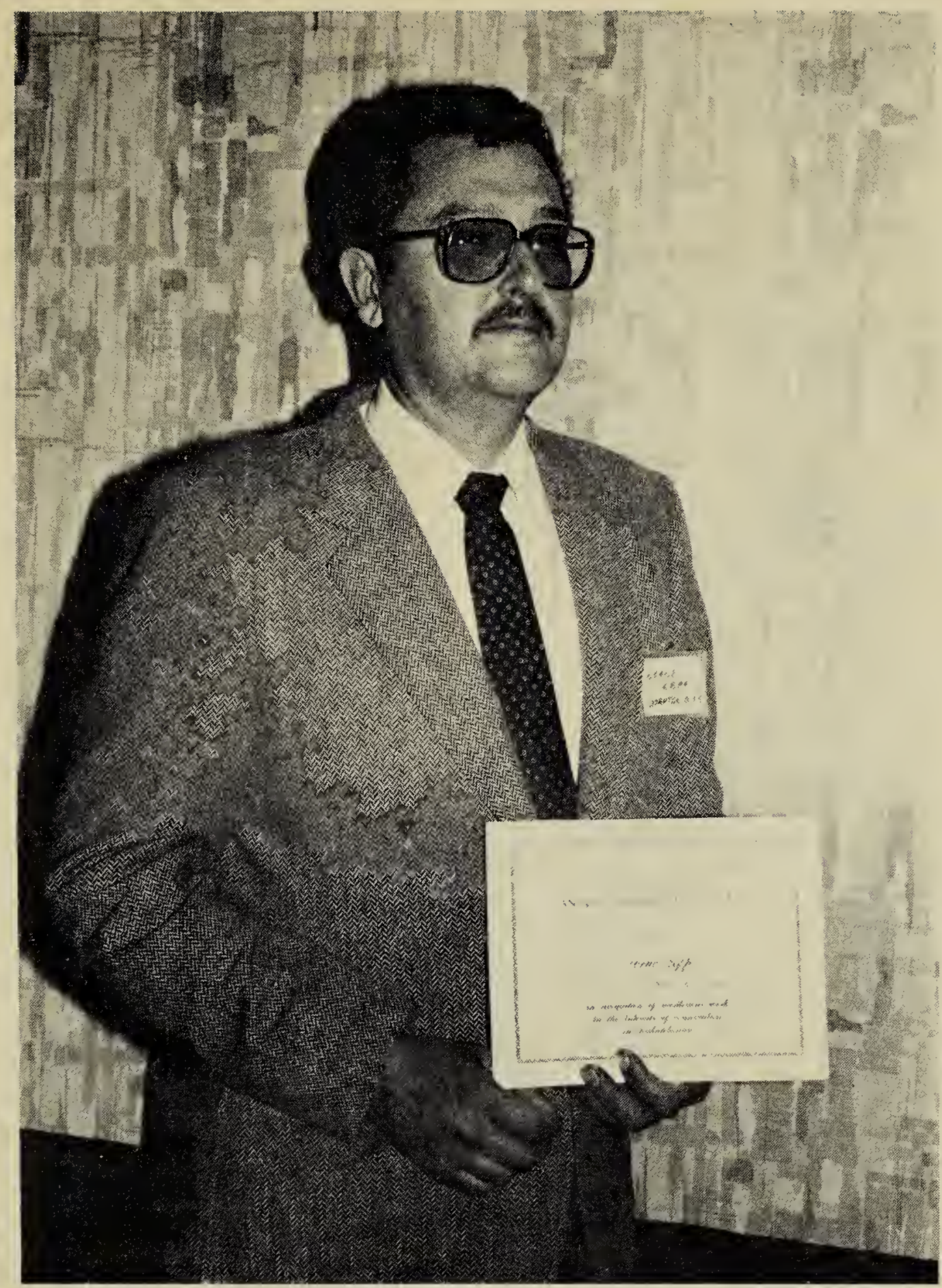

Lorne Lepp, recipient of the Conservation Award Sheina Wait

\section{SASKATCHEWAN NATURAL HISTORY SOCIETY}

(Operating Statement for the year ended 30 September 1985)

INCOME:

Membership - regular

- sustaining \& patron

$3,291.00 \quad \$ 24,549.58$

Donations - general

844.87

230.00

Grants - Sask. Sport Trust (SST)

$5,939.29$ 